\title{
An exploration into Historical and Political factors for the deviation of the Early Church from Scriptural Principles of Government in Reformed Church perspective
}

\author{
Rev. Dr. Humphreys Frackson Zgambo \\ Extraordinary Researcher \\ Unit for Reformational Theology and Development of the South African Society \\ North West University, South Africa \\ Orcid.org: 0000-0003-35791757 \\ Email: hzgambo@gmail.com \\ Doi: https://doi.org/10.46222/pharosjot.102.040
}

\begin{abstract}
The question of church government deals with order and authority of the church. The basic principles for sound church polity base on the Scriptural conviction of the Sovereignty of God and Christ as Head and Ruler of the church. The church moved away from this Scriptural principle due to historical and political factors beyond her authority. The study holds that nowhere in the Scriptures do we find an exclusive picture related to any of the fully developed systems of church government today. The New Testament Scriptures suggest a flexible evolving format of plurality of elders in church polity. The aim of the study is to investigate how some ideas and concepts of church government evolved and developed in the history of the church, how historical and political factors forced the church to shift away from principles of Scripture to advocate for a prelacy theory of government practiced over the centuries. In reformed traditional view, the characteristics of hierarchicalism and clericalism in church structures are not accepted. There is no such a thing as highly hierarchical and clerical or ecclesiastical power in the church of Jesus Christ.
\end{abstract}

Keywords: Church government, hierarchicalism, clericalism, principles, reformed church polity, Presbyterian.

\section{Introduction}

This study briefly explores how some concepts, ideas and theories of church government evolved and developed in the history of the church. The study uses descriptive and interpretive research methodologies suitable for understanding context and deep-seated meanings in particular situations (Drew, et al, 2008:17f). These paradigms in the study provide multiple realities to get relevant information. However, the interpretive paradigm uses qualitative methods to get more knowledge on thick descriptions of phenomena in the study (Marree, 2007:33f). Therefore, this question of church government and church polity deals with concepts of governance, order and authority of the church. The issues of church governance and church polity are mostly visibly shown in the Headship and Lordship of Christ in the New Testament Church (Brand \& Norman, 2004:4-5). Many scholars in ecclesiastical church polity discourse unanimously agree that the New Testament Church does not prescribe a fixed system of government, officers and titles (Vorster, 2011:14-20). The Scriptures only give basic principles of church government that should be applied in structuring of churches and give a clear description of the mission of the church served by the structure established according to given situation (Vorster, 2011:14-20).

The main question stated for this study is: to find out to what extend and how some concepts 
of church government evolved and developed in the history of the church, and how historical and political factors forced the early church to deviate from principles of Scripture and take an approach of prelacy? To assist in the research the following structure is used: definition of concepts of church government and the historical ideas of office of an elder in the Scriptures, the historical and political factors for the church to shift away from principles of Scripture, analysis and evaluation of principles of Scriptures for church government in reformed church perspective and the study will then make a summary and conclusion.

\section{Definition of terms}

\section{The concept of church government}

According to the Oxford Dictionary of Synonyms and Antonyms (Hornby, 2007:197), the word "govern" (verb) means to rule, to preside over, control, be in charge of, command, run, head, manage, oversee, supervise. The setting of rules governing social behavior is to determine, decide, control, constrain, regulate, direct, rule, dictate, shape and affect. Therefore the word "government" (noun), is the system of management used to lead, direct, command, and control an organization. The concept of government composes of a representation of the group of people who are responsible for controlling a state, nation or an organization (Hornby, 2010:649). Erickson (1998:1080) argues that the question of church government in the final analysis deals with issues of authority residing within the church and who is to exercise it. Although the advocates of the various forms of church government agree that God has the ultimate authority, they differ in their conceptions of how or through whom he expresses or exercises it. Clowney (1995:202) holds that our understanding of the government of Christ's church must begin with the Lord himself and his Kingdom authority. He is the Head of the church; His rule is unique and incomparable. The church shows the organic life of Christ's body, she lives as an organism, not just an organization or institution. The church is not like the kingdoms of this world, for it is organized for service not dominion in the world. All government in the church is stewardship: its leaders are servant-managers, who use their authority only to advance the interests of those they represent and serve (Clowney, 1995:202).

\section{The historical idea of office in the Scriptures}

\section{Office of an elder in the Old Testament}

The idea of "office of an elder" originated in the Old Testament (Burtchaell, 1992:25ff). Historically, the office of an elder was first established in the days of Moses to share the burden of leadership (Exodus 18:14-27, Burtchaell, 1992:25ff). The Old Testament Israel was a Patriarchal society, as were most Middle Eastern societies. Respect and deference were shown to older men. Wisdom gained through long life experience was honoured. An inherent authority was concomitant with being an elder of the household, village, or tribe (Burtchaell, 1992:25ff). After the Lord God appeared to Moses in the burning bush, he instructed Moses to gather the elders of Israel together to inform them he was about to deliver Israel from Egyptian bondage and lead them into the Promised Land (Exodus 3:16-4:29). The elders were to go with Moses to represent the people of Israel in their cause before Pharaoh (Exodus 3:18). After giving Moses the law (Exodus 20-23), the Lord instructed him to bring seventy elders to the base of the mountain that they might worship the Lord in confirmation of the covenant (24:1-11). Later the patriarchal cultural tradition was elevated to a "spiritual office".

When Moses had led the people of Israel out of Egypt and they had begun their second year of sojourn in the wilderness, he became overwhelmed with the burden of leadership. The Lord did not grant Moses' petition, but instead instituted a system of shared spiritual leadership through "a number of elders" (Burtchaell, 1992:33f). He instructed Moses to gather seventy men from the elders of Israel who were recognized and proven leaders (v.16). He then demonstrated his approval of the elders by sending His Spirit upon them (vv 17, 24-25). When the Spirit rested upon them, "they prophesied, but they did not continue doing (v.25). This 
visitation of the Holy Spirit served as evidence of God's hand being on them and was, in a sense, their ordination. God earlier had shown his favour to the Levites and Aaronic priests in their ordination (Numbers 8, Leviticus 8). It must be conceived therefore that the purpose of plurality of elders was that spiritual leadership be a shared leadership. The second generation shared in Moses' authority to command the people of God (Deuteronomy 27:1). Joshua continued the practice of shared spiritual leadership through the elders (Joshua 8:10).

Burtchaell (1992:35ff) continues to argue that although the office of elder as spiritual leader was instituted in the days of Moses over 1,400 years before Christ, it did not blossom until the inauguration of the synagogue system in the sixth Century BCE. After the Babylonians destroyed the temple in Jerusalem in 586 BCE and deported the people of Judah, the exiles began to gather for the reading of Scripture, worship, the exposition of Scripture and prayer. The exilic prophets such as Jeremiah $(29: 1)$ and Ezekiel $(8: 1,14: 1,20: 1,3)$ referred to elders as leaders among the people of God during that time. With the spread of the Synagogue system, the prominence of elders grew. After the return from the Babylonian captivity, the rebuilding of the temple under Zerubbabel, and the resulting reinstitution of the Levitical sacrificial system, synagogue continued to be established wherever Jews went in the Mediterranean world, and the rabbis (teachers) and elders grew in prominence (Taylor in Cowan, 2004:78f).

\section{Office in the New Testament Church}

Smith (1976:15-16) asserts that during pre-Christian period the Greeks, Romans and Jews, each had official representative boards composed of several men elected or elders were appointed from the people. The Greeks had gerousia or town board, the Romans had a senate and the Jewish synagogue had a presbytery. It is quite possible that the early New Testament Church followed a somewhat similar pattern (Banks, 1993:131ff). The New Testament suggests an evolving format starting with the twelve Apostles in the early chapters of Acts moving to a delegation of responsibility in Acts chapter 6 and later to a more complex system of official boards in Acts 15 and 20. The formation of local church government was based upon spiritual principles that may be expressed in different ways depending upon the size of the church, culture and gifted men present.

Brand and Norman (2004:11) argues that in the New Testament, presbyter (elder) and overseer (bishop) appear to be words used to refer the same office or role. According to Rensburg (2009:443) the relevant New Testament Greek terms and ideas for the meanings that are regarded as important in a bibliological study of the "service" of the "elder" are Greek: episcopos shepherd or overseer, (to have the ministerial responsibility) and etymologically related word presbuteros elder, prosmainoi care as shepherd (1 Peter 5:1-3, Acts 1:20, 20:28, 1 Timothy 3:1). From Titus $1: 7$ it is evident that presbuteros and episkopos are use synonymously, what goes for episkopos is therefore also applicable to presbuteros and vice versa. God gives certain persons as gifts to the congregation as shepherd and minister. The shepherds guard the flock, for the congregation is the flock of God (Acts 20:28). Within the early church an elder was a person with the responsibility to rule with regard to religious ethical matters and had to provide guidance. An elder had to lead and help the congregation that was entrusted to him like a shepherd to his herd (Rensburg, 2009:443ff). The basic meaning of presbuteroi are "elders" with the emphasis on the "ripeness of judgment" rather than just on "age," and gives the translational responsibility as "a group of elders" (Acts 22:5, 1 Timothy 4:14).

In the New Testament again there was no set pattern for selection and appointment of church officers. Some early church leaders were appointed by God directly and the church was notified of the choice through inspired prophets for example in cases of Paul and Barnabas (Acts 13:1-3); possibly Timothy (1 Timothy 1:18, 4:14). Here the joint actions of appointment by the Holy Spirit and congregations in other places (Acts 6:1-6, 13:1-3, 15:22-28) leave open 
the possibility that men chose in some way but with the approval of the Holy Spirit could be described as placed in the church by the Holy Spirit (Ferguson, 1988:322, 311).

Vorster (2011:14-20) holds that many scholars in ecclesiastical church polity discourse unanimously agree that the New Testament does not prescribe a fixed system of government, officers and titles. It only gives basic principles of church government which should be applied in the structuring of churches and a clear description of the mission of the church which should be served by the structure established according to given situation. Brand and Norman (2004:4-5) argue that the issue of governance of the church is mostly visibly seen in the Lordship of Christ. The church exists by and under His Lordship. He builds the church and calls it "my church" (Matthews 28:18). Christ instructs the church that its task is to teach followers and observe all things that He has instructed. The governance of the church is also manifested in the quest of believers to conform their ministries and relationships to the teaching of the Word of God (Brand \& Norman, 2004:4-5). Christ's Lordship and authority are evidenced in that He appoints officers who minister within the church and gives gifts for ministry to the church (Ephesians 4:7-12, 1 Corinthians 12:5-6).

\section{The historical and political factors for deviation of the early church from the Scriptural principles of church government}

The critical question is to find out to what extent and how some concepts of church government evolved and developed in the history of the church, and how historical and political factors forced the early church to deviate from principles of Scripture and take an approach of prelacy. According to Cowan (2004:85-90f), the early church moved away from scripturally based "elder" (Greek presbuteros) representative church system to an episcopalian "bishop" (overseer) authoritarian church theory so early in her history for the following three basic factors: persecution and effort to maintain theological orthodoxy; geographical and political factors and efficiency of church operations.

\section{Persecution and maintenance of theological orthodoxy}

Cowan (2004:85-90f) contends that during Jesus' ministry, he had warned his disciples that they would face persecution. Indeed the church suffered persecution just as he had predicted. Christians suffered at the hands of the Jewish leaders as well as leaders of the pagan religious and the Roman government. Peter and John were arrested by the Sanhedrin (Acts 4:1-22, 5:17-42), imprisoned, and beaten (Acts 5:40). Stephen the deacon was stoned to death by a Jewish mob (Acts 7). Saul of Tarsus ravaged the church (Acts 8:1-3, 9:1-2). After Saul's conversion, the former persecutor became persecuted (Acts 9:23-29ff). James, son of Zebedee and the brother of John, was beheaded by Herod Agrippa 1; the first of the twelve apostles to be martyred (Acts 12:1-2). Meyer (1969:22-24) argues that until Titus Vespasianus destroyed Jerusalem in 70 CE and Christian Jews fled the holy city during the siege as Jesus had warned them to do (Matthews 24-25), Christianity was regarded by the Gentile world as a part of Judaism (similar to the Pharisees, Sadducees, the Essenes, and the Zealots). That event marked a sharper demarcation of Christians from Judaism. As more Jews were converted, Jewish opposition to Christianity and persecution intensified. With a Jewish revolt led by the false messiah Bar-Cochba ("the son of the star") during 132-135 CE, Christian Jews were singled out for persecution by the revolutionaries. Thereafter, Christian Jews were no longer considered a sect within Judaism by either the Jews or the civil authorities. As paganism became threatened by Christianity, Christians were persecuted by religious leaders, a development evinced by the riot of the silversmiths at Ephesus (Acts 19:21-41).

Cowan (2004:85-88f) argues that politically the first of ten imperial Roman persecutions of the church was instituted by Nero in $64 \mathrm{CE}$, by whose orders Paul and Peter were martyred. Christians endured the last of these imperial persecutions under Diocletian Galerius in 304$311 \mathrm{CE}$. Persecutions varied in intensity and duration; some were local, others were empirewide. Persecutions over the years made the bishop-presbyter's (senior pastor's) role more 
authoritative as he passed on the apostolic teachings and had custody of scriptures, commentaries, liturgical materials, and ecclesiastical correspondence and records. Moreover, the bishop - presbyter's role became more authoritative as the church exercised pastoral discipline over its members who succumbed to moral laxity or fell into heresies. In this manner, the "monarchial bishops" arose. Ignatius of Antioch in 117 CE mentioned this monoepiscopacy (only one bishop as the head of a local church). In reflecting upon earlier centuries of the Church, fourth century church father Jerome in CE 342-420 noted: "Ancient presbyters were the same as bishops, but gradually all the responsibility was deferred to a single person, that the thickets of heresies might be rooted out". Therefore, persecution and maintenance of theological orthodoxy factors played a major role in the deviation of the early church from the Scriptural principles of church government.

\section{Geographical and political factors of the early centuries}

The churches where the apostles had personally labored were especially respected: Jerusalem, Antioch, Smyrna, Corinth, Ephesus, Philippi, Thessalonica, and particularly Rome. These churches were regarded as "mother churches" and the wisdom of their bishoppresbyters as heirs to the apostolic teachings was especially valued (Fisher, 1913:62ff). Moreover, the church took Christ's Great Commission (Acts 1:8) seriously and spread the good news throughout the Roman Empire, beginning in Jerusalem and extending to the nations. By the late second century (the time of Irenaeus and Tertullian) bishops had begun to oversee several churches within a geographical area. In the mid -third century Cyprian proposed the idea of the prominence of Peter and those who followed him as bishops of Rome, though he regarded the other apostles with high honor and authority. Cyprian called Rome the matrix et radix ("womb and root") of the church (Fisher, 1913:62ff).

According to Meyer (1969:43-44), when the imperial persecution of Christians under Diocletian ended, his successor, Constantine, declared Christianity to be a legal religion by the Edict of Milan in 313 CE. Theodosius 1 the Great, Roman Emperor from 379 to $395 \mathrm{CE}$ established the Christian state and persecuted pagans. The structure of the Roman government influenced not only church government but also its theology and liturgy. The Western branch of the church, centered in Rome, was patterned after Roman courts of law. Western theology developed in a logical, rhetorical fashion. The Eastern branch of the church, centered in Constantinople, was patterned after the pomp and ceremony of the imperial court. Its liturgy developed more elaborately; its theology was more mystical than Western theology. The church spread first within urban centers and then took root in more rural areas. By the Council of Nicaea in 325 CE urban bishops were given prominence over rural bishops. Five of the major cities of the Roman Empire had become centers for Christian expansion: 1. Jerusalem, the mother Church, 2. Antioch of Syria, the first Gentile Church, 3. Alexandria, the most prominent Roman city in North Africa, 4. Rome, the capital of the Roman Empire and 5. Constantinople, the Eastern capital after the rise of Constantine (Cowan, 2004:86-89ff).

The bishops of the churches of these five "patriarchal cities" were especially influential and respected, in a manner similar to the way the senior pastor of the largest church of a particular denomination within a state is usually shown deference today(Cowan, 2004:86-89ff). Rome was regarded as "first among equals;" Constantinople was second. Callixtus, bishop of Rome in CE 217-222, claimed to be Pontifex maximus (highest pontiff) and episcopus episcoporum (bishop of bishops), though Tertullian sarcastically denounced such pretentions. By the midfifth century CE, Leo 1 claimed to have authority over the entire church, although the Eastern branch of the Church did not recognize is supremacy. Rome's prominence was further enhanced over time because heresies and heretics had been more successfully dealt with there, than in Alexandria and Constantinople (Cowan, 2004:86-89ff). Therefore, the geographical and political factors of the early centuries also played a major role for the deviation of the church from the Scriptural principles of church government. 


\section{The efficiency factor of the church}

The prelacy or episcopal system came to be seen an efficient means of operation, especially given its political modeling after Roman civil government and its effective administrative form. An authoritative bishop, with the decision - making power and ability to delegate responsibilities to others, was more efficient than shared system of leadership. A more authoritative episcopacy developed over time in the West for a number of reasons. Rome was not only the sole patriarchal city in the West, but capital of the Empire. Thus, the bishop of Rome became the most prestigious of all the bishops and patriarchs. Unlike the Eastern Church, the Church in Rome also began to transition from Greek to Latin by the mid-second century and was thereafter able to resolve theological conflicts more readily because Latin did not have the nuances of meaning problematic to Greek. The Western Church grew more rapidly than the Eastern Church because it was more successful in evangelization and missions. With the barbarian invasions, the Church, particularly the Western Church, became a more cohesive force in the empire (Meyer, 1969:23-28).

Moreover, the theory of Petrine supremacy and attempts by bishops of Rome to exercise universal authority led to its preeminence. Even though Rome fell to barbarian invasion in 410 $\mathrm{CE}$, many barbarians later converted to Christianity and became part of the Western Church (Smith, 1976:21-22). The Eastern Church was the first confronted with the rise of Islam in 633$732 \mathrm{CE}$, and within one hundred years saw the loss of the patriarchal cities of Jerusalem, Antioch and Alexandria (Smith, 1976:21-22). Christians in the East look to the patriarch of Constantinople as a politically unifying figure. Tensions between the Western and Eastern Church grew, fed in part by Rome's claim to universal authority and eventuating in the great Schism of $1054 \mathrm{CE}$, in which the patriarch of Constantinople and the Roman Pope mutually anathematized each other. During the middle Ages, the Roman Papacy's power, influence and wealth grew to its high-water mark (Cowan, 2004:86-89f).

However, the political and theological upheavals did not initially disrupt episcopacy. Despite the Reformation in England, the Church of England retained an Episcopal Church government. Nor did the Lutherans show much concern about reforming church polity. Therefore, the efficiency factor of the church played a major role for the deviation of the early church from the Scriptural principles of church government.

\section{Evaluation and analysis of the basic principles of church government in the New Testament Scriptures in reformed church perspective}

\section{The principle of the supremacy of Christ}

The principle of church government for the supremacy of the reign of Christ in every detail of the life of the church is characterized in the New Testament Church. In the New Testament Scriptures, Christ is the King, Lord and Prince of peace (Isaiah 9:4-12, cf Revelation 19:16, Chapters 21, 22). Christ is the King of the Kingdom of God and Head of the people of God, the church (Matthews 16:18, 1 Corinthians 15:24-28, Ephesians 1:22, Philippians 2:8-11) Christ is the Head of the church and source of all its authority. In essence, the Kingdom of God is about the reign of God through Christ in very conscience of the life of the church. Christ supremely reigns differently in all respects from earthly kings. All believers in Christ are unconditionally bound to obey the Word of the King. As Christ is the only sovereign Ruler of the church, His Word is the only word that is law in the absolute sense. Vorster (2011:8-10) holds that the Kingdom of God is indeed the central aspect in Biblical revelation. The primary idea of the Kingdom of God in Scripture is that of the rule of God established and acknowledged in the hearts of sinners by the powerful regenerating influence of the Holy Spirit, insuring them of the inestimable blessings of salvation. This rule is realized on earth, but will not reach its culmination until the visible and glorious return of Jesus Christ (Berkhof, 1969:568). The present realization of Kingdom reign is spiritual and invisible, to deliver all people from the slavery of sin. This reign has already been manifested in the coming of Christ, 
but will be revealed in its completeness at the end of time. The reign of God is a present and future reality (Ridderbos, 1975:343f).

According to reformed tradition, the legitimate church polity must be characterized on the conviction of the Sovereignty of God, Christ as Head and Ruler and must be fundamental to understand the context of the New Testament Church (Koffeman \& Smit, 2014:40). Clowney (1995:202) holds that our understanding of the government of Christ's church must begin with the Lord Himself and His Kingdom authority. He is the Head of the church; His rules through gifted church officers. The Scriptures never refers to a human being as a "head of the church" as claimed by the Roman Catholic Church or Episcopal Church view. This title exclusively belongs to Jesus Christ alone. He is the only Head of each local assembly. The church has no head on its own (Viola, 2008: 295). Therefore, in the Reformed tradition, there is no such a thing as hierarchical and ecclesiastical power. A notion of personal hierarchy is structurally avoided (Janssen, 2000:15f).

\section{The principle of government by the presbuteroi elders}

The principle of government ruled by the presbuteroi' (elders') representatives are characterized in the New Testament with influence from the Jewish system. Du Toit (1998:257) holds that during the Seleucid regime, the Sanhedrin appeared as a convocation of the spiritual elders (heads of families -Greek gerousia) representing the nation (Du Toit, 1998:257). The Jewish synagogue had a presbytery (Banks, 1993:131ff, Spijker, 1996:424. It appears that in each of them, large board elected from its midst bishops - official supervisors with much authority; and deacons - servants who carried out orders (Smith, 1976:15-16).

The New Testament Scriptures suggest a flexible evolving administrative format of church polity and order starting with the twelve Apostles in the early chapters of Acts moving to a delegation of responsibility of deacons in Acts chapter 6 and later to a more complex system of official council in Acts 15 and 20. The New Testament Church continued the practice of accepting "elders" as spiritual leaders, a practice obviously endorsed by Christ's own Apostles. The death of the Apostle James in about 44 CE (Acts 12:2) was a catalytic factor that marked a transition in the Jerusalem Church. Up to that point the church there had been under the direct spiritual leadership of the Apostles who had remained even after the stoning of Stephen around $35 \mathrm{CE}$. About the time of the persecution by Herod Agrippa 1 (James execution), Luke's record begins to regularly mention "elders" in the Jerusalem Church. Barnabas and Saul delivered the famine relief offering from the Gentile Churches to the "elders" of Jerusalem (Acts 11:30).

Gelder (2000:181) asserts that leaders in the church must have a mature Christian character. Anyone who is going to be a leader in the church must demonstrate maturity in exercising the fruit of the Spirit (Galatians 5:22-23). Scripture assumes that leaders in the church were appointed based on their gifts and skills. The Spirit gives spiritual gifts to all people in the church. Some gifts relate directly to leadership. It is the Spirit who prompts, motivates, and energizes a person with the appropriate gifts to exercise leadership role (Ephesians 4:11-14). Elders were the representatives of the people, they formed a part of all ecclesiastical assemblies, and partake, in all authoritative acts, equally with the teaching elders and in which, by a series of judicatories, rising one above another, each individual church is under watch and care of its appropriate judicatory and the whole body, by a system of review and control, is bound together as one homogeneous community (Hall, et al 1994:76). Therefore, hierarchicalism, clericalism, and ecclesiastical influence and power are rejected in entirety.

\section{The principle of priesthood of believers}

The principle of priesthood of all believers is also characterized in New Testament Church. In the Old Testament times people did not approach God directly. A priest acted as intermediary between God and sinful man. With Christ's death on the cross, resurrection and ascension to 
the right hand of the Father, everything changed. Now people can come directly into God's presence without fear (Hebrews 4:16) and are given responsibility of bringing others to him also (2 Corinthians 5:18-21. The members of the church are prophets, priests and kings under Christ, so that appointed leaders should be attentive to listen to what members hear from God, as the church together seeks to discern God's will to do it. 1 Peter 2:9 says: "But, you are a chosen generation, a royal priesthood, a holy nation, and His own special people that you may proclaim the praises of Him who called you out of darkness into His marvellous light."

When people are unified with Christ as members of his body, they join in his priestly work of reconciling God and man. Hunter (1950:304) holds that Calvinism taught the sense of personal worth and human dignity principally because John Calvin was an outright uncompromising exponent of essential democracy in church and state. The principle of the sovereignty of the people is the gift of Calvinism to the contemporary world. Each one is given at least one spiritual gift and will be held responsible for their faithful use of it for the benefit of others. No one in the church is excluded from having to use their spiritual gifts to serve others (Hunter, 1950:304). The church is a "body" where everyone contributes (1 Corinthians 12:1-26, Romans 12:3-8). Individual Christians have received a delegated ministry by means of their relationship with Christ, membership of the church, participation in the Word and sacrament.

\section{The principle of servant-leadership}

The principle of servant-leadership is characterized in the New Testament Church. A powerful example of Christian leadership is where authority operates solely for service. Jesus Christ is quoted in Mark 10:44-45 as saying: "For whoever will be the greatest shall be the servant of all, for even the son of man came not to be served but to serve and give his life as a ransom for many people."

In Christ's Kingdom, service is the way to go ahead to greatness. The desire to be on top will hinder, not help. Rather than seeking to have your needs met, look for the ways you can minister to the needs of others. True greatness comes in serving others (1 Peter 5:1-4). The function of biblical leaders is not to do the work exclusively, but to provide a model and an example in the areas of corporate responsibility, and also to train and lead the members in the exercise of their own gifts for the church to grow (Wagner, 1976:63f). This is explicit in the purpose of the Spirit's gifting, which is for the common good (1 Corinthians 12:7). In the church, leaders must show humility and take the example of Christ. Leaders are therefore esteemed, not because of their office but because of their work (Hunter, 1950:304ff). Therefore, the nature of Christian leadership in the New Testament Church is characterized by servantleadership.

\section{The principle of ecumenical ecclesiastical connectionism}

The principle of ecumenical ecclesiastical connectionism is characterized in the New Testament Church during times of crisis (Acts 8:1-8 cf 12:1ff, Brand \& Norman, 2004:112113). In Acts 1-4, 7-8, it was persecution which forced the Christians out of Jerusalem and drove them into Judaea and Samaria. Therefore, persecution united the early church and helped spread the gospel across the frontiers. Consequently, God brought great results from the suffering. In Scripture, it was recorded: "the entire community of believers in one locale" (Acts 8:1), "the entire community of believers connected in suffering with joy to several regions" to hear a report from the Apostle Paul and enjoyed relative peace (Acts 9:31). The elders represented from several congregations conferred on doctrine at Jerusalem (Acts $11: 22,18: 22)$, elders met to represented several local congregations on dietary laws and circumcision at Antioch (Acts 15:3), there was an all congregations conference in Jerusalem (Acts 12:1-5, 15:4) and a regional congregations conference met at Ephesus (Acts 20:17, 28). Viola (2008:117) argues that since the church is the body of Christ in a given location, a local church must include different team leaders of Christ's body at a particular place. The church 
must also accept "other members" as a team from different ethnic identity "just as Christ accepted us" (Romans 15:7).

Therefore, the principle of ecumenical ecclesiastical conventionalism in the church promotes accountability, dependency, and mutual submission among congregations (Brand \& Norman, 2004:112). Calvin affirms this inclusive doctrine of church polity by citing the two great ecclesiological maxims of Cyprian of Carthage: "You cannot have God as your Father unless you have the church as your mother of all." And "Outside the church there is no hope, or remission of sins nor any salvation" (Calvin, 1989). The basic responsibility for the state of the congregation rests on the "elder", even to such degree that in Reformed Church political definitions the existence of a congregation depends on whether there are elders present. A congregation can be without an episkopos and it would be constituted as a temporary shortcoming that has to be addressed quickly. A congregation can also be without deacons and that would also be viewed as a temporary shortcoming that has to be addressed quickly. But a congregation without presbyters (elders) cannot exist in ecclesiology (Momberg, 2009:458). Therefore, an office of elder as instituted by Christ who deemed it necessary in the church is a foundational point of departure for dealing with the matter in church government and church polity discourse (Momberg, 2009:458).

\section{Summary of the study}

The study briefly explored how some concepts, ideas and theories of church government evolved and developed in the history of the church and how historical and political factors forced the early church to move away from principles of Scripture to take a prelacy approach of government. According to Cowan (2004:85-90f), the early church moved away from scripturally based "elder" (Greek presbuteros) representative church system to an episcopalian "bishop" (overseer) authoritarian church theory so early in her history for three basic factors: persecution and effort to maintain theological orthodoxy; geographical and political factors and efficiency of church operations.

The study established that nowhere in the Scriptures do we find an exclusive picture related to any of the fully developed systems of church government today. The New Testament Scriptures suggest a flexible evolving format of plurality of elders in church polity. Christ is the Head of the church and source of all its authority. Christ supremely reigns differently in every detail of the church and in all respects from earthly kings. He is the King of kings, Lord of lords and Prince of peace (Isaiah 9:4-12, cf Revelation 19:16, Chapters 21, 22). Therefore all believers in Christ are unconditionally bound to obey the Word of the King. As Christ is the only sovereign Ruler of the church, His Word is the only word that is law in the absolute sense.

The study established that the system of government for Ecumenical ecclesiastical connectionism is well characterized in the New Testament Church (Brand \& Norman, 2004:112-113). In Scripture it was recorded: "the entire community of believers connected in one locale" (Acts 8:1), "the entire community of believers connected in several regions" (Acts 9:31). The basic meaning of presbuteroi are "elders" with the emphasis on the "ripeness of judgment" rather than just on "age," and gives the translational responsibility as "a group of elders" (Acts 22:5, 1 Timothy 4:14). In the New Testament there was no set pattern for selection and appointment of church officers. The elder is a visible sign within the worshiping body of the congregation of the apostolic task of the church. In the New Testament there was no set pattern for selection and appointment of church officers.

According to the Reformed view, legitimate church polity must be rooted in Holy Scriptures and the confession regarding the church provides the normative guidelines for the church (Haitjema in Du Plooy, 1982:37). Viola (2008:129) holds that during the New Testament world, local churches were completely unified in the apostolic teaching and practice. They held that the church is one under One Head Jesus Christ. All believers in the New Testament Church in a specific location lived as members of one organized family under the leadership of the 
"office" of an elder and deacon. As a result, the early church began rapidly expanding and brought together more people of diverse cultures which was both a challenge and a blessing (Acts 8:1-39, 13:1, 18:22, Romans 16:1). The contemporary church must always take the responsibility to adopt policies which will re-organize the structures which will meets the needs of the members and foster greater health and growth within the life of church. In reformed view, the characteristics of hierarchicalism and clericalism in church structures are not accepted. The basic principle for sound church polity is based on the Scriptural conviction of the Sovereignty of God and Christ as Head and Ruler of the church.

\section{Conclusion}

In conclusion, the study established that the authority of the church resides primarily in the church courts such as the session of the local church, consistory, with presbyteries and general assembly possesses only such ecclesiastical authority as are granted them by the several local churches (Brand \& Norman, 2004:124-125). Just as the reign of God is realized in the coming and teaching of Christ, it is also realized in the community which results from the work of Christ, namely the church (Vorster, 2011:8ff). Christ does not rule the church by force, but subjectively by His Spirit, which is operative in the church, and objectively by the Word of God as the standard of authority. From the Reformed point of view, church polity must be concerned with the proclamation of the gospel of Jesus Christ, the administration of sacraments and the exercise of discipline - thus the administration of the keys of the kingdom of God (Van't Spijker, 1993:317, 1996:192ff). Therefore, church polity must lead to a system of church government which provides the channel for the true doctrine through which the church can be built up. In light of the Word of God, church polity should determine the fundamental principles of justice, order and method of government in the church.

For Smit (1996:2ff), Calvin's radical rejection of mere human exercise of authority in the church is strikingly encompassed in his exegesis of Ephesians 4:5. These guidelines are the foundation on which Reformed church polity as a "sacral science of governing the visible church," can be built (Du Plooy, 1982:54-55). The New Testament Church adopted the approach of exercising authority through offices of elders and courts of the church in obedience to the Word of God and illumination of the Holy Spirit. In the New Testament Scriptures, Christ is the King and Lord of the Church. Christ is the King of the Kingdom of God and Head of the people of God, the church (Matthews 16:18, 1 Corinthians 15:24-28, Ephesians 1:22, Philippians 2:8-11), Christ is the Head of the church and source of all its authority. Therefore, the contemporary church, must take the responsibility to recover this lost theory of church government based upon the principles of New Testament Scripture; where church polity is based upon spiritual and theological principles expressed in different ways depending upon the size of the church, culture and gifted men present in reformed church perspective.

\section{References}

Banks, R. (1993). Church Order and Government in Dictionary of Paul and His Letter, Illinois: Inter-Varsity.

Berkhof, L. (1969). Systematic Theology, London: Banner of Truth.

Brand, C. O. \& Norman, R. S. (2004). Perspectives on Church Government 5 Views, Nashville: B \& H Publishing.

Burtchaell, J. T. (1992). From Synagogue to Church, Cambridge: Cambridge University.

Calvin, J. (1989). Calvin's institutes: a new compend, Edited by Hugh T. Kerr. Louisville, Ky: Westminster/John Knox Press. 
Cowan, S. B. (2004). Who Runs the Church? Four Views on Church Government, Grand Rapids: Zondervan.

Clowney, E. P. (1995). The Church: Contours of Christian Faith, Downers Grove: Inter-Varsity.

Drew, C. J. et al. 2008. Designing and conducting Research in Education. Thousand Oaks: Sage.

Du Plooy, A. le R. (1982). Reformed Church Polity: Essays and Topics, North West University: Potchefstroom: TPT.

Du Toit, A. B. et al. (1988). Guide to the New Testament 2: The New Testament Milieu, Halfway House: Orion Publishers.

Erickson, M.J. (1998). Christian theology. Grand Rapids, MI: Baker Academic.

Ferguson, E. (1988). Encyclopedia of Early Christianity, New York: Garland.

Fisher, G. P. (1913). The History of the Church, London: Hodder \& Stoughton.

Gelder, C. V. (2000). The Essence of the Church: A Community Created by the Spirit, Grand Rapids: Baker Books.

Haitjema, T. L. in Du Plooy, A. le R. (1982). Reformed Church Polity: Essays and Topics, North West University: Potchefstroom: TPT.

Hall, D. W. \& Hall, J. H. (1994). Paradigms in Polity: Classic Readings in Reformed and Presbyterian Church Government, Grand Rapids: William B. Eerdmans Publishing Company.

Hornby, A.S. et al. (2015). Ethnicity. Oxford Advanced Learner's Dictionary of Current English, Oxford: Oxford University.

Hunter, M. A. (1950). The Teaching of Calvin: A Modern Interpretation, London: James Clarke \& Company.

Janssen, A. J. (2000). Constitutional Theology: Notes on the Book of the Church Order of the Reformed Church in America, Grand Rapids: Eerdmans.

Koffeman, L. J. \& Smit, J. (2014). The foundation and Relevance of Reformed Church Polity: As a Theological Science. Protestant Church Polity in Changing Contexts 2.Case Studies. Proceedings of the International Conference, Utrecht, the Netherlands 7-10 November 2011.

Marree, K. 2007. First Steps in Research. Pretoria: Van Schaik.

Meyer, C.S. (1969). The church: from Pentecost to the present, Chicago: Moody Bible Institute.

Momberg, H. (2009). The Office of Elder: Church Historical Indications. Report Deputies Doctrinal Matters. Report Study Group. Office of the Elder, 92: 139, Synod of Reformed Churches of South Africa, 2009.

Rensburg Van, F. J. (2009). Bibliological Study on the Elder in the New Testament Church: Report Deputies Doctrinal Matters: Report Study Group 4. Office of the Elder, 92: 139, Synod of the Reformed Churches of South Africa, 2009.

Ridderbos, H. (1975). The Coming of the Kingdom, Philadelphia: The Presbyterian and Reformed. 
Smit, C. J. (1996). A Governing of the Heart: Mainly seen by John Calvin, Potchefstroom: Potchefstroom Theological Publications (PTP).

Smith, M.A. (1976). The church under siege, Leicester: Inter-Varsity.

Taylor, L. R. (in Cowan, S. B) (2004). Who Runs the Church? Four Views on Church Government, Grand Rapids: Zondervan.

Van't Spijker, W. T. (1996). The Ecclesiastical Offices in the Thought of Martin Bucer, Leiden: E. J. Brill.

Viola, F. (2008). Pursuing the Dream of Organic Christianity: Re-imagining Church, Colorado Springs: David C. Cook.

Vorster, J. M. (2011). An Introduction to Reformed Church Polity, Potchefstroom:

Potchefstroom Theological Publications (PTP).

Wagner, P. (1976). Your Church Can Grow, California: Regal Books. 